\section{A) Check for updates}

Cite this: Org. Chem. Front., 2019, 6 , 2385

Received 2nd April 2019,

Accepted 29th April 2019

DOI: $10.1039 /$ c9qo00462a

rsc.li/frontiers-organic

\title{
Synthesis and antiproliferative activities of OSW-1 analogues bearing 2-acylamino-xylose residues $\uparrow$
}

\author{
Lijun Sun, (D) a,b Ruina Wang, ${ }^{c}$ Xiaobo Wang, ${ }^{c}$ Yongjun Dang, (D) ${ }^{c}$ Wei Li (D) *b,d and \\ Biao Yu (D)*b
}

OSW-1 and SBF-1 are well studied saponins with exceptionally potent antitumor activities. Herein, we report the syntheses of a library of 38 C22-ester analogues bearing 2-acylamino xylose residues. SAR studies show that the introduction of the 2-acylamino xylose residues could further increase the antitumor activities as many as 40 folds than those of SBF-1 and the $(1 \rightarrow 3)$-disaccharide linkage is crucial to the activities. A highly potent probe (3) bearing photoactivatable and clickable residues has been identified

\section{Introduction}

OSW-1 (1), a naturally occurring steroidal saponin isolated from the bulbs of Ornithogalum saundersiae (Fig. 1), ${ }^{1,2}$ is known for its exceptionally potent antiproliferative activity against tumor cells. With $\mathrm{IC}_{50}$ values in nanomolar range, OSW-1 is 10 to 100 times more active than several clinical antitumor drugs, such as cisplatin. ${ }^{3}$ In addition, normal cell lines were found to be less sensitive to OSW-1, ${ }^{3,4}$ making it a potential candidate for developing antitumor drugs. Consequently, extensive efforts have been devoted into its synthetic and SAR studies. ${ }^{5-21}$ Among the numerous natural and synthetic analogues, it is noteworthy that SBF-1 (2), an artificial 22-ester analogue that can be readily prepared via a stereoselective aldol reaction, displays similar or even better antitumor activity. ${ }^{22}$ Therefore, SBF-1 (2) has been used as an accessible alternative in biological studies. ${ }^{23-26}$

Despite the tremendous efforts in the synthetic realm, ${ }^{27-33}$ the mechanism of the antitumor activity of OSW-1 still remains elusive. Applying a synthetic probe derived at the $3-\mathrm{OH}$ of the xylose moiety to the pull-down assay, Shair and co-

\footnotetext{
${ }^{a}$ Department of Chemistry, University of Science and Technology of China, 96 Jinzhai Road, Hefei, Anhui 230026, China

${ }^{b}$ State Key Laboratory of Bio-organic and Natural Products Chemistry, Center for Excellence in Molecular Synthesis, Shanghai Institute of Organic Chemistry, Chinese Academy of Sciences, 345 Lingling Road, Shanghai 200032, China.E-mail: byu@sioc.ac.cn

${ }^{c}$ Key Laboratory of Metabolism and Molecular Medicine, the Ministry of Education, Department of Biochemistry and Molecular Biology, School of Basic Medical Sciences, Fudan University, Shanghai 200032, China

${ }^{d}$ Department of Medicinal Chemistry, China Pharmaceutical University,

24 Tong Jia Xiang, Nanjing, Jiangsu 210009, China. E-mail: wli@cpu.edu.cn

$\dagger$ Electronic supplementary information (ESI) available. See DOI: 10.1039/ c9qo00462a
}

workers disclosed that oxysterol binding protein (OSBP) and its paralog ORP4L, both of which are usually related to sterol and lipid metabolism, could be targeted by OSW-1. ${ }^{34,35}$ Huang and co-workers found that the cytotoxic potency of OSW-1 relied on the homeostasis of calcium regulation, such as sodium-calcium exchange on the plasma membrane. ${ }^{4,36} \mathrm{Wu}$ and co-workers suggested OSW-1 induced apoptosis related to Bcl-2 and caspase- $8 .{ }^{37}$ Given these controversial results, it is highly possible that OSW-1 is able to target multiple proteins. Thus, development of new OSW-1 probes to identify other unknown binding proteins is of great interest. Recently, Sakurai and co-workers reported the preparation and cytotoxicity of several OSW-1 probes with the fluorescent or clickable functionalities installed at either $3-\mathrm{OH}$ or $4-\mathrm{OH}$ of the xylose moiety, some of which were equipped with diazirine

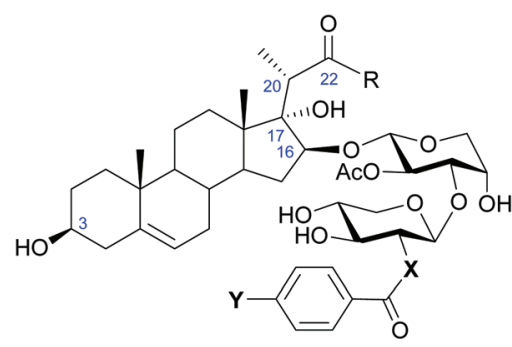

$$
\begin{aligned}
& \text { OSW-1 (1), } R=5^{\prime}, X=O, Y=O M e \\
& \mathrm{SBF}-1(2), \mathrm{R}=\mathrm{s}^{5} \mathrm{O} X X^{11}, X=\mathrm{O}, \mathrm{Y}=\mathrm{OMe} \\
& 3, R=5 \xi^{5}+\lambda N^{11}, X=N H, Y=\frac{\xi}{\xi} N_{N}^{N}
\end{aligned}
$$

Fig. 1 The structure of OSW-1 (1), synthetic analogue SBF-1 (2), and the designed probe 3 in the present work. 
residues for photoaffinity labeling..$^{38-42}$ However, their application in the target identification has yet to be reported.

Based on SBF-1 (2) which is easier to prepare and similarly active compared to OSW-1, we envisioned a duo-labeled analogue (3) as a new probe of OSW-1 (Fig. 1). An azido group was attached at the end of the aliphatic side chain of the aglycone, which could couple with biotin or fluorescent groups via a click reaction; a diazirine group was introduced at the xylose residue, which could lead to conjugation to the binding proteins via a photoactivatable carbene insertion reaction. Previous SAR studies have disclosed the crucial necessity of the two acyl groups on the disaccharide for maintaining the potent antitumor activities, ${ }^{3,43-45}$ but a slight modification of the $p$-methoxybenzoyl $(\mathrm{MBz})$ group at the $\mathrm{C} 2$ of the xylose moiety has been proved tolerable. ${ }^{3,42-44}$ Hence, C2 of the xylose residue would be an ideal position for the photoaffinity labeling by replacing the original $\mathrm{MBz}$ group with a diazirinesubstituted benzoyl group. ${ }^{46}$ Due to the poor stability of the photosensitive diazirine group, its introduction should be scheduled at a late stage. To this end, an amino group was envisioned to replace the original 2-hydroxyl group on the xylose residue, ${ }^{47}$ it would be readily coupled with the commercially available diazirine-substituted benzoic acid at the final stage. In addition, this strategy would result in a series of OSW-1 analogues bearing 2-acylamino-xylose by coupling with different carboxylic acids. Herein, we report their chemical synthesis and antiproliferative activities against tumor cell lines.

\section{Results and discussion}

The synthesis commenced with the preparation of a sterol aglycone bearing a C22-ester chain with an azido group added at the terminal position, following modification of the previous approach to the synthesis of SBF-1 (2). ${ }^{22}$ Thus, $16 \alpha-\mathrm{OH}$ ketone 4 was prepared from dehydroepiandrosterone via four steps with an overall yield of $60 \%$ (Scheme 1). 12-Azidododecyl propionate $\mathbf{5}$ was then attached to ketone $\mathbf{4}$ under the conditions of LiHMDS in THF at $-10{ }^{\circ} \mathrm{C}$, providing diol 6 in 53\% yield with the resulting tertiary $17-\mathrm{OH}$ and 21-methyl in the desired $\alpha$ - and $S(\mathrm{C} 20)$-orientations, respectively. Upon treatment of diol 6 with TPAP-catalyzed oxidation in the presence of NMO led to the corresponding ketone 7 in a satisfactory $80 \%$ yield; subsequent reduction with $\mathrm{NaBH}_{4}$ and $\mathrm{CeCl}_{3}$ in THF and $\mathrm{H}_{2} \mathrm{O}$ smoothly turned over the original $16 \alpha-\mathrm{OH}$ of 6 , furnishing the desired aglycone 8 with $16 \beta-\mathrm{OH}$ ready for glycosylation.

On the other hand, we adopted an effective protocol to synthesize 2-amino-2-deoxy-D-xylose from D-xylose (Scheme 2). Treatment of $\mathrm{D}$-xylose (9) with $\mathrm{Ac}_{2} \mathrm{O}$ and pyridine at $0{ }^{\circ} \mathrm{C}$ fully converted 9 into tetraacetyl xylose, which underwent bromination under the conditions of $33 \% \mathrm{HBr} / \mathrm{AcOH}$ in $\mathrm{CH}_{2} \mathrm{Cl}_{2}$; subjection of the resulting xylosyl bromide to a suspension of $\mathrm{Zn}$ and $\mathrm{NH}_{4} \mathrm{Cl}$ in $\mathrm{CH}_{3} \mathrm{CN}$ provided xylal 10 in an excellent 96\% yield (based on 9). ${ }^{48,49}$ A successful introduction of an equatorial adizo group to $\mathrm{C} 2$ was realized by Lemieux's azidonitration
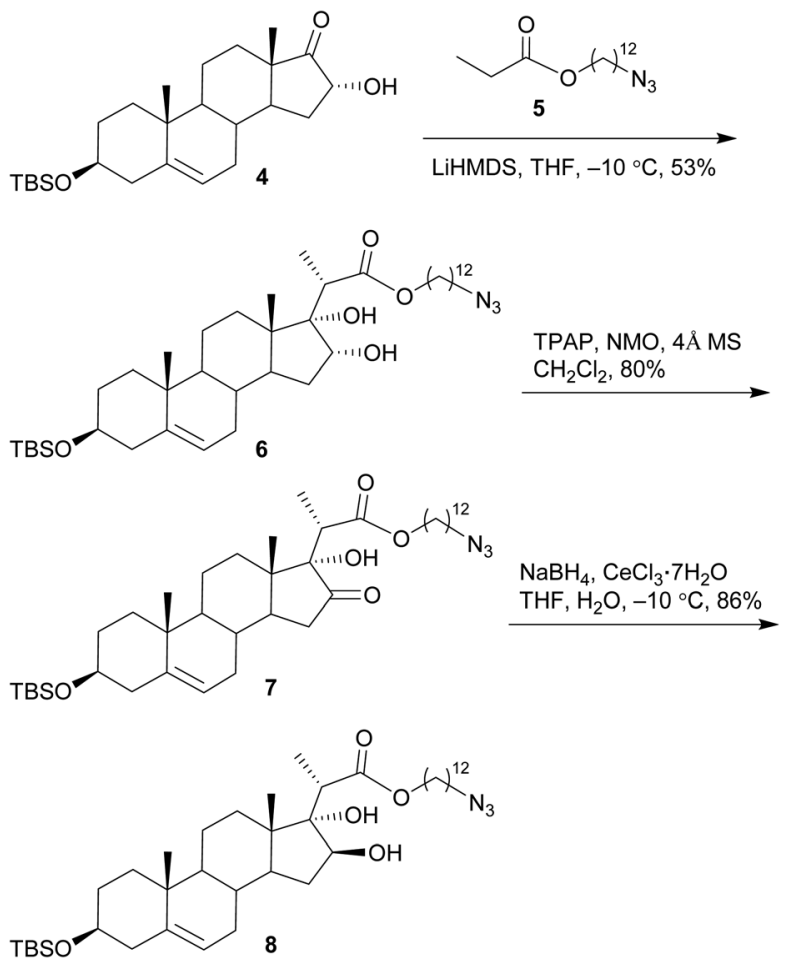

Scheme 1 Synthesis of aglycone 8.
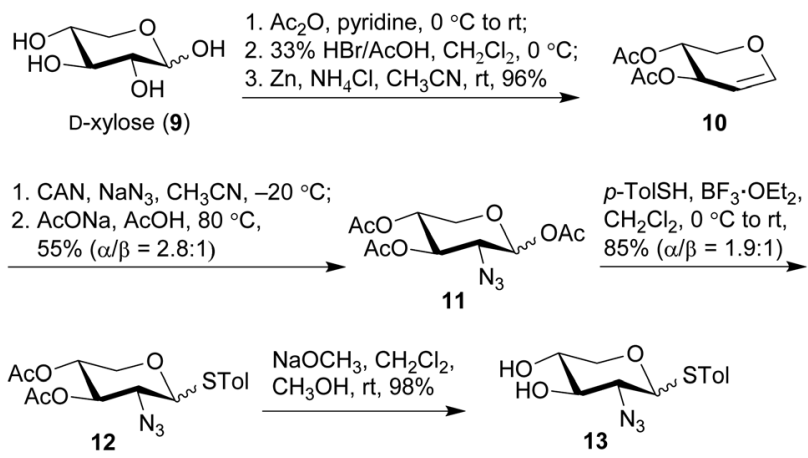

Scheme 2 Synthesis of tolylthio 2-azido-2-deoxy-xylopyranoside 13.

of xylal 10 with $\mathrm{CAN}$ and $\mathrm{NaN}_{3}$ in $\mathrm{CH}_{3} \mathrm{CN}$ at $-20{ }^{\circ} \mathrm{C} ;{ }^{47,50-52}$ the nascent anomeric nitro group was immediately replaced with an acetoxy group to provide $\mathbf{1 1}$ as a pair of inseparable anomers $(\alpha / \beta=2.8: 1) .{ }^{51}$ Next, acetates 11 were smoothly converted into thioglycosides 12 in $85 \%$ yield under the conditions of $p$-TolSH and $\mathrm{BF}_{3} \cdot \mathrm{OEt}_{2}$ in $\mathrm{CH}_{2} \mathrm{Cl}_{2} \cdot{ }^{53}$ Although both 11 and 12 were inseparable anomers, the $\alpha$ - and $\beta$-anomers of 13 obtained after deacylation could be partially separated and therefore their structures were unambiguously confirmed.

The anomeric thiol group of $\mathbf{1 3}$ could act as both protecting and leaving groups, due to its good stability toward acidic, basic and reductive conditions as well as the effective activation by specific reagents such as NIS. The selective protection for 2- $\mathrm{NH}_{2}, 3-\mathrm{OH}$, and 4-OH, however, encountered difficulties. For the purpose of ensuring the $\beta$-selectivity in the later 
glycosylation, a protecting group capable of neighboring participation would be required at $2-\mathrm{NH}_{2}$. Thus, a range of protecting groups was examined and phthalimido (Phth) group was found efficient to secure the $\beta$-selectivity. Other protecting groups such as Boc, Fmoc, Troc, and Teoc were excluded owing to the poor performance in either their installations or glycosylation of the arabinosyl acceptor. On the other hand, the choice of protecting groups for $3-\mathrm{OH}$ and $4-\mathrm{OH}$ was greatly constrained by the conditions of introducing Phth group that required basic DBU in heated toluene, wherein the widely-used TES groups in the previous synthetic work were easily removed. Therefore, thioglycosides 13 were treated with 2,3butanedione and $\mathrm{BF}_{3} \cdot \mathrm{OEt}_{2}$ in $\mathrm{MeOH}$ in the presence of $\mathrm{CH}(\mathrm{OMe})_{3}$ to give base-stable bisacetal 14 in a good $81 \%$ yield (Scheme 3). ${ }^{54,55}$ Reduction of the 2-azido group with $\mathrm{Ph}_{3} \mathrm{P}$ in THF and $\mathrm{H}_{2} \mathrm{O}$ afforded the desired 2-amino group on 15, which was subsequently protected with Phth group to afford phthalimide 16 in $90 \%$ yield under the conditions of phthaloyl dichloride and $\mathrm{DBU}$ in toluene at $120{ }^{\circ} \mathrm{C} .{ }^{56}$ Similar to the anomers depicted in Scheme 2, the anomers of $\mathbf{1 4}$ were hardly separable, while those of $\mathbf{1 5}$ and $\mathbf{1 6}$ could be partially separated for the purpose of structural characterization. Meanwhile, counterparts of these compounds with the anomeric $\alpha$-benzyl group were also synthesized (see ESI $\dagger$ for details) for the preparation of other types of xylosyl donors instead of the thioglycoside donor. Although all these counterparts were single $\alpha$-anomers and their isolation and identification were much easier compared to the present thioglycosides, the Phth group encountered unexpected saturation during the hydrogenolysis of the anomeric benzyl group.

With the 2-amino-thioxyloside donors 16 at hand, a regioselective glycosylation of arabinosyl diol 17 was conducted under the conditions of NIS and TMSOTf in the presence of $4 \AA$ A MS (Scheme 4). ${ }^{6}$ Surprisingly, unlike most of the previously reported glycosylation of diol 17 with xylosyl donors that mainly led to the $(1 \rightarrow 3)$-linked disaccharide, ${ }^{32}$ the present glycosylation with 2-amino-xylosyl donors 16 led to $(1 \rightarrow 4)$-linked disaccharide as the major product. Similar 4-OH selectivity has been reported in the previous synthesis of OSW-1
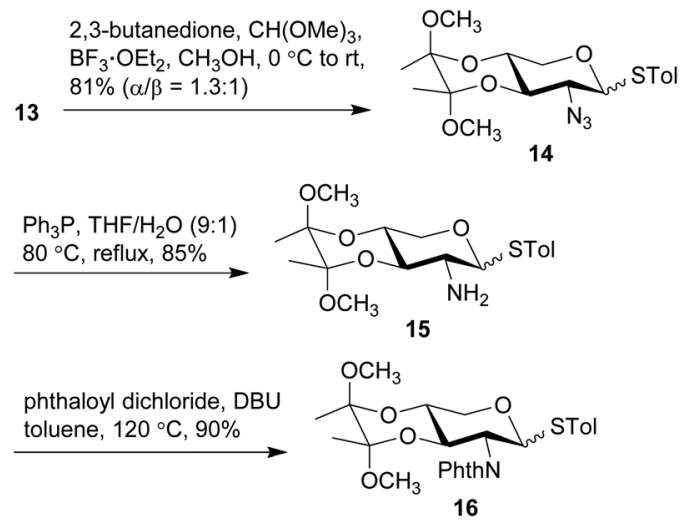

Scheme 3 Synthesis of 2-amino-thioxyloside 16.

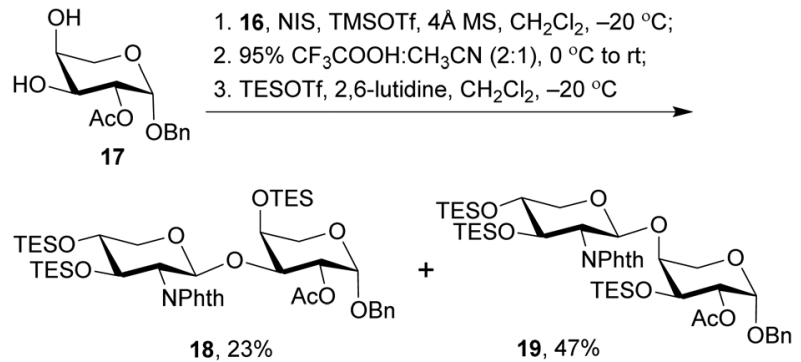

Scheme 4 Synthesis of disaccharides 18 and 19.

analogues, ${ }^{54,55,57,58}$ including a careful investigation conducted by Pakulski and co-workers. They attributed this unusual 4-OH selectivity to a novel equatorial 4-OH of arabinose with the ${ }^{1} \mathrm{C}_{4}$ conformation constrained by the intramolecular hydrogen bonding between $3-\mathrm{OH}$ and the cisanomeric oxygen atom of arabinoside ${ }^{55,58}$ However, this could not be used to explain the selectivity in our glycosylation because the anomeric oxygen atom on $\mathbf{1 7}$ is trans to $3-\mathrm{OH}$ and no hydrogen bonding could be formed. Apparently, the regioselectivity of 3,4-diol arabinoside relies not only on arabinoside itself, but also on the xylosyl donors. Additionally, we found that the replacement of Phth group on $\mathbf{1 6}$ with Troc or Fmoc increased the 3-OH selectivity, but unfortunately trisaccharides from the bis-glycosylation of both $3-\mathrm{OH}$ and $4-\mathrm{OH}$ of 16 were also generated in a significant amount.

The $(1 \rightarrow 3)$-linked and $(1 \rightarrow 4)$-linked disaccharide products obtained from the glycosylation of $\mathbf{1 7}$ with $\mathbf{1 6}$ were only partially separable and both of them could be used in the preparation of OSW-1 analogues, so no further optimization was conducted. Our synthesis continued with the replacement of the butane-bisacetal group with TES groups, the removal of which would be much more reliable at a late stage. ${ }^{58}$ Thus, the mixture was treated with $\mathrm{CF}_{3} \mathrm{COOH}$ and $\mathrm{CH}_{3} \mathrm{CN}$ to cleave the acetal, and subsequent protection with TES groups under the conditions of TESOTf and 2,6-lutidine provided the separable $(1 \rightarrow 3)$-linked and $(1 \rightarrow 4)$-linked disaccharides 18 and 19 in $23 \%$ and $47 \%$ yield (three steps based on 16), respectively. Their structures were carefully characterized by 2D NMR, particularly HMBC spectra. Both 18 and 19 were employed in the following synthesis of OSW-1 analogues.

Hydrogenolysis of the anomeric benzyl group of disaccharide 18 with 10\% $\mathrm{Pd} / \mathrm{C}$ in EtOAc afforded the desired hemiacetal 20 in 57\% yield (Scheme 5), although a small part of the Phth group was also found saturated. After activation of 20 under the conditions of $\mathrm{CCl}_{3} \mathrm{CN}$ and $\mathrm{DBU}$ in $\mathrm{CH}_{2} \mathrm{Cl}_{2}$, subjection of the resulting imidate $\mathbf{2 1}$ to the glycosylation of sterol aglycone 8 in the presence of TMSOTf at $-20{ }^{\circ} \mathrm{C}$ led to the desired 22 in 52\% yield. Subsequent removal of the Phth group under the conditions of $85 \% \mathrm{~N}_{2} \mathrm{H}_{4} \cdot \mathrm{H}_{2} \mathrm{O}$ in EtOH at $60{ }^{\circ} \mathrm{C}$ was accompanied by the partial cleavage of the acetyl group and therefore led to a mixture. Interestingly, TES groups that were usually considered as acid- and base-labile mainly remained intact under these conditions. The nascent free 

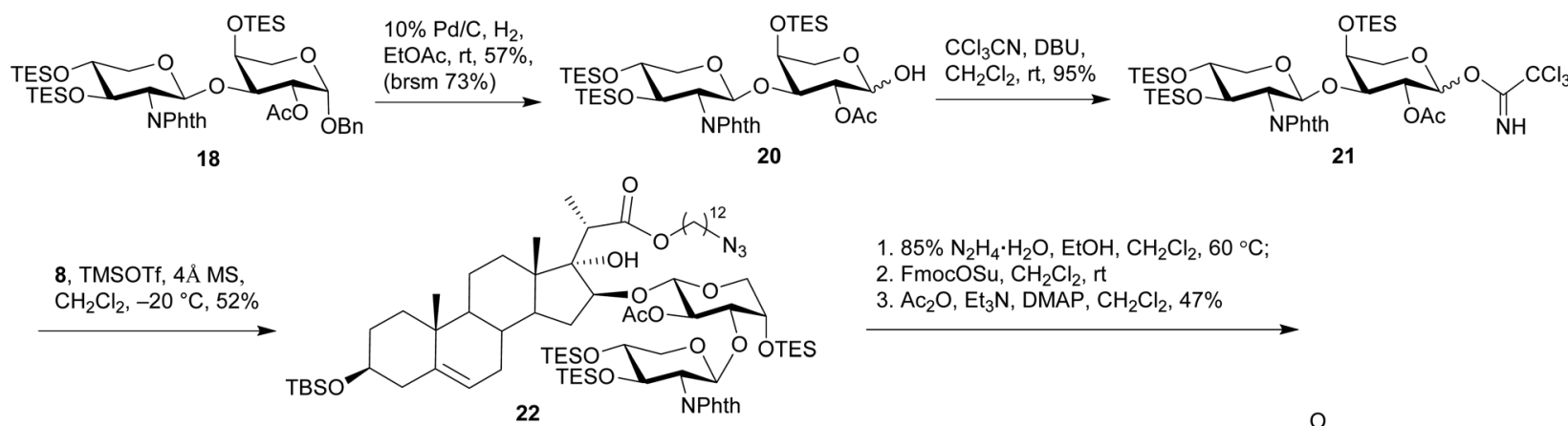

1. $85 \% \mathrm{~N}_{2} \mathrm{H}_{4} \cdot \mathrm{H}_{2} \mathrm{O}$, EtOH, $\mathrm{CH}_{2} \mathrm{Cl}_{2}, 60^{\circ} \mathrm{C}$;

2. $\mathrm{FmocOSu}, \mathrm{CH}_{2} \mathrm{Cl}_{2}$, it

3. $\mathrm{Ac}_{2} \mathrm{O}, \mathrm{Et}_{3} \mathrm{~N}, \mathrm{DMAP}, \mathrm{CH}_{2} \mathrm{Cl}_{2}, 47 \%$

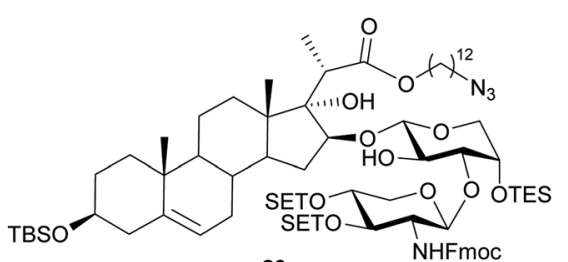

23
1. $\mathrm{Et}_{2} \mathrm{NH}, \mathrm{CH}_{2} \mathrm{Cl}_{2}, \mathrm{rt}$;

2. $\mathrm{RCOOH}, \mathrm{HATU}$, DIPEA, $\mathrm{CH}_{2} \mathrm{Cl}_{2}, \mathrm{rt}$; 3. $\mathrm{CF}_{3} \mathrm{COOH}, \mathrm{CH}_{2} \mathrm{Cl}_{2}, \mathrm{rt}, 10 \% \sim 44 \%$

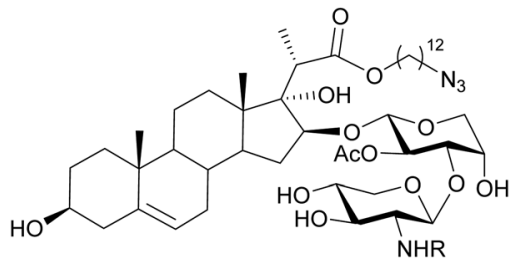

3, 24-47
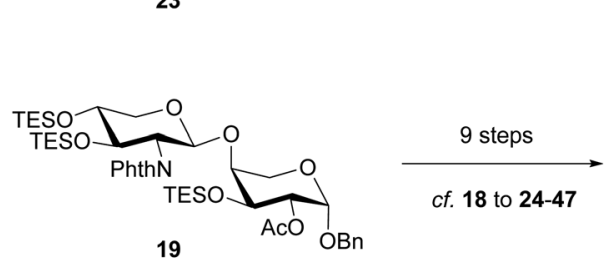<smiles>C=C1C[C@H](O)CC[C@]1(C)C(C)CC</smiles>

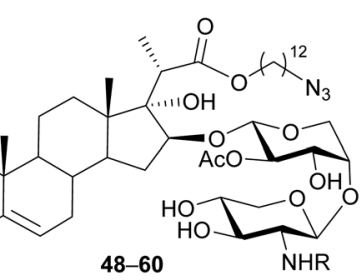<smiles>[R]=CCC(C)(C)C(C)=O</smiles>

24

25<smiles>[Y]C(=O)c1ccc(OC)cc1</smiles>

29, 50<smiles>[Y4]C(=O)CCCCCCCCC</smiles>

26<smiles>[Z17][13CH2]CCCCCCC/C=C(/CCCCCCCC)[N+](=O)[O-]</smiles><smiles>CC(C)(C)CCCc1ccc(N(CCCl)CCCl)cc1</smiles><smiles>[Y6]C(=O)c1ccc(C2(C(F)(F)F)N=N2)cc1</smiles><smiles>CC(=O)Oc1ccccc1C(C)=O</smiles><smiles>COc1ccc(C(C)(C)C)cc1F</smiles>
$31^{\mathrm{F}}$<smiles>[Y6]C(=O)c1c(F)cc(F)cc1F</smiles>

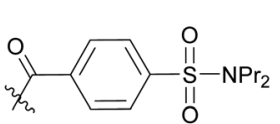

34,55<smiles>CC(=O)C(C)c1ccc(CC(C)C)cc1</smiles><smiles>[Y]C(=O)C1(c2ccc(Cl)cc2)CC1</smiles><smiles>CC(=O)C(C)c1ccc(F)c(-c2ccccc2)c1</smiles><smiles>COc1ccc2ccc([C@@H](C)C(C)=O)cc2c1</smiles><smiles>CC(=O)c1cc2cc(F)ccc2o1</smiles><smiles>CC(=O)C(C)(C)c1cccc2ccccc12</smiles><smiles>CC(=O)C1CN(C2CC2)c2cc(F)c(F)cc2C1=O</smiles><smiles>CC(=O)c1cc2cc3c4c(c2oc1=O)CCCN4CCC3</smiles><smiles>CC(=O)C1(C(=O)Nc2ccc(F)cc2)CC1</smiles>

43<smiles>CC(=O)C(C)(C)Oc1ccc(C2CC2(Cl)Cl)cc1</smiles><smiles>COc1ccc2c(c1)c(CC(C)=O)c(C)n2C(=O)c1ccc(Cl)cc1</smiles><smiles>CC(=O)Oc1cccc2c1C(=O)c1c(OC(C)=O)cc(C(C)=O)cc1C2=O</smiles>

46, 59<smiles>CC(=O)CC1=C(C)/C(=C/c2ccc(S(C)=O)cc2)c2ccc(F)cc21</smiles>

47,60

Scheme 5 Synthesis of OSW-1 analogues bearing 2-N-acyl-2-deoxyxylose unit. 
Table 1 Antiproliferative activities of the OSW-1 analogues

\begin{tabular}{|c|c|c|c|c|c|c|c|}
\hline \multirow[b]{2}{*}{ Compounds } & \multicolumn{3}{|c|}{$\mathrm{IC}_{50}(\mathrm{nM})$} & \multirow[b]{2}{*}{ Compounds } & \multicolumn{3}{|c|}{$\mathrm{IC}_{50}(\mathrm{nM})$} \\
\hline & Jurkat & MDA-MB-231 & CRL1999 & & Jurkat & MDA-MB-231 & CRL1999 \\
\hline 24 & 6.56 & 2.43 & N/A & 25 & 5.57 & 0.85 & N/A \\
\hline 26 & 162 & 24.8 & N/A & 27 & 153 & 136 & N/A \\
\hline 28 & 7.10 & 27.0 & 12.0 & 29 & 0.11 & 0.51 & 0.40 \\
\hline 3 & 1.80 & 3.70 & 11.0 & 30 & 7.26 & 0.88 & N/A \\
\hline 31 & 0.59 & 0.75 & 0.72 & 32 & 0.44 & 0.76 & 1.50 \\
\hline 33 & 0.46 & 1.40 & 0.68 & 34 & 1.00 & 4.10 & 4.40 \\
\hline 35 & 164 & 33.7 & N/A & 36 & 8.60 & 11.0 & 56.0 \\
\hline 37 & 29.0 & 69.0 & 220 & 38 & 2.50 & 7.90 & 11.0 \\
\hline 39 & 0.75 & 0.64 & 1.40 & 40 & 24.0 & 56.0 & 130 \\
\hline 41 & 3.50 & 6.00 & 9.00 & 42 & 6.80 & 6.90 & 23.0 \\
\hline 43 & 3.50 & 8.50 & 28.0 & 44 & 83.0 & 260 & 2950 \\
\hline 45 & 20.0 & 39.0 & 30.0 & 46 & 2.40 & 4.70 & 18.0 \\
\hline 47 & 5.40 & 10.0 & 160 & 50 & 600 & 2400 & 3200 \\
\hline \multirow[t]{2}{*}{53} & 1300 & 5000 & 3900 & SBF-1 (2) & 4.30 & 15.0 & 17.0 \\
\hline & & & & Taxol & 3.8 & 2.6 & 138 \\
\hline
\end{tabular}

amino group in this mixture was selectively protected by a Fmoc group with FmocOSu, and the remaining free hydroxyl groups were re-acetylated to give 23 in $47 \%$ yield (based on 22). Next, Fmoc was removed with $\mathrm{Et}_{2} \mathrm{NH}$ in $\mathrm{CH}_{2} \mathrm{Cl}_{2}$ at rt, and the released amino group was then coupled with a wide range of carboxylic acids in the presence of HATU and DIPEA at rt. Final removal of all the silyl groups with $\mathrm{CF}_{3} \mathrm{COOH}$ in $\mathrm{CH}_{2} \mathrm{Cl}_{2}$ at rt furnished 25 OSW-1 analogues $(3,24-47)$ bearing $(1 \rightarrow 3)$ linked 2- $N$-acyl-2-deoxyxylose residues, including the designed probe 3 with the aryl diazirine moiety for future photo-crosslinked reaction. Similar procedures were employed on disaccharide 19 to synthesize $13(1 \rightarrow 4)$-linked analogues 48-60 bearing different acyl residues at the 2-amino group.

Employing the CellTiter Glo Luminescent cell viability assay, we measured the antiproliferative activities of these newly synthesized OSW-1 analogues against three representative cell lines (Table 1), i.e., Jurkat (human leukemia cells) for suspension tumor cells, MDA-MB-231 (human breast cancer cells) for adherent tumor cells, and CRL1999 (human aorta smooth muscle cells) for normal cells. SBF-1 (2) and Taxol were used as positive controls in the evaluation. In general, most of the $(1 \rightarrow 3)$-linked OSW-1 analogues bearing 2 - $\mathrm{N}$-acyl-2deoxyxyloses $(\mathbf{3}, \mathbf{2 4}-\mathbf{4 7})$ displayed potent antiproliferative activities with $\mathrm{IC}_{50}$ values lower than $10 \mathrm{nM}$. Among them, compound 29 with the same $\mathrm{MBz}$ group as the natural OSW-1 showed the strongest activity and its $\mathrm{IC}_{50}$ reached as low as $0.11 \mathrm{nM}$ against Jurkat $\mathrm{T}$, which is 40 times more potent than SBF-1 (2) and taxol. In fact, all the $(1 \rightarrow 3)$-linked analogues (3, 29-34) with benzoyl-type groups, including the designed photoaffinity probe 3 , displayed better activities than SBF-1 (2). These comparisons clearly indicated that the replacement of the xylose residue with 2-amino-2-deoxyxylose would increase the antiproliferative activities. On the other hand, the introduction of short aliphatic acyl groups into the amino group, such as Ac (24) or butyryl group (25) rather than benzoyl group, could still retain the activities. But long aliphatic acyl groups on analogues 26 and 27 were found to increase the $\mathrm{IC}_{50}$ to around $100 \mathrm{nM}$. It is noteworthy that all the analogues (24-27) with aliphatic acyl groups showed stronger antiproliferative activities against MDA-MB-231 than Jurkat cells, whereas other analogues were usually more effective on Jurkat than MDA-MB-23 cells. These results suggest that the types of acyl groups on the xylose moiety could affect the antitumor selectivity, presumably related to the growth of tumors as suspension cells or adherent cells.

Although all the $(1 \rightarrow 3)$-linked OSW-1 analogues $(\mathbf{3}, \mathbf{2 9 - 3 4})$ with benzoyl-type groups exhibited excellent activities against tumor cell lines, they were also comparably cytotoxic to normal cells CRL1999. Replacing the benzoyl groups with more complex acyl groups could result in several safer analogues to normal cell lines. For instance, analogues 44 and 47 are 30 times more potent against Jurkat than CRL1999 cells. This is similar to the antitumor selectivity found on taxol. More analogues and activity data are still required for further analysis of the SAR on the antitumor selectivity.

On the other hand, analogues bearing the $(1 \rightarrow 4)$-linked disaccharides were found to be dramatically less active. The most potent one was compound $\mathbf{5 0}$ bearing the $\mathbf{M B z}$ group, however, its $\mathrm{IC}_{50}$ value even on the more sensitive Jurkat was as high as $600 \mathrm{nM}$, which is 6000 folds as much as $0.11 \mathrm{nM}$ of its $(1 \rightarrow 3)$-linked counterpart 29 . This is consistent with the previous reports, wherein several $(1 \rightarrow 4)$-linked analogues were synthesized but found inactive at a concentration of $10 \mu \mathrm{M} .^{18,57}$ These results confirmed that the $(1 \rightarrow 3)$-linkage in the disaccharide was essential to maintain the potent antiproliferative activities of OSW-1 analogues.

\section{Conclusions}

An effective route was established for the synthesis of OSW-1 analogues bearing 2-acylamino xylose residues. A library of 25 $(1 \rightarrow 3)$-linked and $13(1 \rightarrow 4)$-linked disaccharide analogues were prepared accordingly, including a photoaffinity and clickable 
probe 3. The evaluation of their antiproliferative activities indicated that the replacement with 2-aceylamino xylose residues could significantly increase the activities with the lowest $\mathrm{IC}_{50}$ value being down to $0.11 \mathrm{nM}$. In addition, the $(1 \rightarrow 3)$-linkage of the disaccharide was confirmed to be crucial to retain the potent activities. Studies on target protein identification with probe 3 are in progress and the results will be reported in due course.

\section{Conflicts of interest}

There are no conflicts to declare.

\section{Acknowledgements}

We acknowledge the financial support from the National Natural Science Foundation of China (21432012, 21621002 and 21672248), E-Institutes of Shanghai Municipal Education Commission (E09013), the Strategic Priority Research Program of the Chinese Academy of Sciences (XDB20020000), and the K. C. Wong Education Foundation.

\section{Notes and references}

1 S. Kubo, Y. Mimaki, M. Terao, Y. Sashida, T. Nikaido and T. Ohmoto, Phytochemistry, 1992, 31, 3969-3973.

2 V. L. Challinor and J. J. De Voss, Nat. Prod. Rep., 2013, 30, 429-454.

3 Y. Mimaki, M. Kuroda, A. Kameyama, Y. Sashida, T. Hirano, K. Oka, R. Maekawa, T. Wada, K. Sugita and J. A. Beutler, Bioorg. Med. Chem. Lett., 1997, 7, 633-636.

4 Y. Zhou, C. Garcia-Prieto, D. A. Carney, R.-h. Xu, H. Pelicano, Y. Kang, W. Yu, C. Lou, S. Kondo, J. Liu, D. M. Harris, Z. Estrov, M. J. Keating, Z. Jin and P. Huang, J. Natl. Cancer Inst., 2005, 97, 1781-1785.

5 C. Guo and P. L. Fuchs, Tetrahedron Lett., 1998, 39, 1099-1102.

6 S. Deng, B. Yu, Y. Lou and Y. Hui, J. Org. Chem., 1999, 64, 202-208.

7 W. Yu and Z. Jin, J. Am. Chem. Soc., 2001, 123, 3369-3370.

8 J. W. Morzycki and A. Wojtkielewicz, Carbohydr. Res., 2002, 337, 1269-1274.

9 Q.-h. Xu, X.-w. Peng and W.-s. Tian, Tetrahedron Lett., 2003, 44, 9375-9377.

10 L. Deng, H. Wu, B. Yu, M. Jiang and J. Wu, Bioorg. Med. Chem. Lett., 2004, 14, 2781-2785.

11 B. Shi, P. Tang, X. Hu, J. O. Liu and B. Yu, J. Org. Chem., 2005, 70, 10354-10367.

12 J. W. Morzycki, A. Wojtkielewicz and S. Wołczyński, Bioorg. Med. Chem. Lett., 2004, 14, 3323-3326.

13 Y. Matsuya, S. Masuda, N. Ohsawa, S. Adam, T. Tschamber, J. Eustache, K. Kamoshita, Y. Sukenaga and H. Nemoto, Eur. J. Org. Chem., 2005, 803-808.
14 H.-J. Qin, W.-S. Tian and C.-W. Lin, Tetrahedron Lett., 2006, 47, 3217-3219.

15 A. Wojtkielewicz, M. Długosz, J. Maj, J. W. Morzycki, M. Nowakowski, J. Renkiewicz, M. Strnad, J. Swaczynová, A. Z. Wilczewska and J. Wójcik, J. Med. Chem., 2007, 50, 3667-3673.

16 P. Tang, F. Mamdani, X. Hu, J. O. Liu and B. Yu, Bioorg. Med. Chem. Lett., 2007, 17, 1003-1007.

17 J. Xue, P. Liu, Y. Pan and Z. Guo, J. Org. Chem., 2008, 73, 157-161.

18 D. Zheng, L. Zhou, Y. Guan, X. Chen, W. Zhou and P. Lei, Bioorg. Med. Chem. Lett., 2010, 20, 5439-5442.

19 Y. Guan, D. Zheng, L. Zhou, H. Wang, Z. Yan, N. Wang, H. Chang, P. She and P. Lei, Bioorg. Med. Chem. Lett., 2011, 21, 2921-2924.

20 J. Maj, J. W. Morzycki, L. Rárová, J. Oklešt'ková, M. Strnad and A. Wojtkielewicz, J. Med. Chem., 2011, 54, 3298-3305.

21 C. Liu, A.-p. Wang, L. Jin, Y. Guo, Y. Li, Z. Zhao and P. Lei, Tetrahedron, 2016, 72, 4091-4102.

22 B. Shi, H. Wu, B. Yu and J. Wu, Angew. Chem., Int. Ed., 2004, 43, 4324-4327.

23 W. Li, R. Song, X. Fang, L. Wang, W. Chen, P. Tang, B. Yu, Y. Sun and Q. Xu, Biochem. Pharmacol., 2012, 84, 172181.

24 W. Li, Z. Ouyang, Q. Zhang, L. Wang, Y. Shen, X. Wu, Y. Gu, Y. Shu, B. Yu, X. Wu, Y. Sun and Q. Xu, Cell Death Dis., 2014, 5, e1581.

25 A. Elgehama, W. Chen, J. Pang, S. Mi, J. Li, W. Guo, X. Wang, J. Gao, B. Yu, Y. Shen and Q. Xu, Cancer Lett., 2016, 372, 82-88.

26 W. Chen, X. Qian, Y. Hu, W. Jin, Y. Shan, X. Fang, Y. Sun, B. Yu, Q. Luo and Q. Xu, J. Pharmacol. Sci., 2018, 138, 271-278.

27 J. W. Morzycki and A. Wojtkielewicz, Phytochem. Rev., 2005, 4, 259-277.

28 B. Yu, Y. C. Zhang and P. P. Tang, Eur. J. Org. Chem., 2007, 5145-5161, DOI: 10.1002/ejoc.200700452.

29 S. Lee, T. G. LaCour and P. L. Fuchs, Chem. Rev., 2009, 109, 2275-2314.

30 J. J. Forsman and R. Leino, Chem. Rev., 2011, 111, 33343357.

31 B. Yu, J. Sun and X. Yang, Acc. Chem. Res., 2012, 45, 1227-1236.

32 Y. Tang, N. Li, J.-a. Duan and W. Tao, Chem. Rev., 2013, 113, 5480-5514.

33 Y. Yang, S. Laval and B. Yu, Adv. Carbohydr. Chem. Biochem., 2014, 71, 137-226.

34 A. W. G. Burgett, T. B. Poulsen, K. Wangkanont, D. R. Anderson, C. Kikuchi, K. Shimada, S. Okubo, K. C. Fortner, Y. Mimaki, M. Kuroda, J. P. Murphy, D. J. Schwalb, E. C. Petrella, I. Cornella-Taracido, M. Schirle, J. A. Tallarico and M. D. Shair, Nat. Chem. Biol., 2011, 7, 639-647.

35 L. Albulescu, J. R. Strating, H. J. Thibaut, L. van der Linden, M. D. Shair, J. Neyts and F. J. van Kuppeveld, Antiviral Res., 2015, 117, 110-114. 
36 C. Garcia-Prieto, K. B. Riaz Ahmed, Z. Chen, Y. Zhou, N. Hammoudi, Y. Kang, C. Lou, Y. Mei, Z. Jin and P. Huang, J. Biol. Chem., 2013, 288, 3240-3250.

37 J. Zhu, L. Xiong, B. Yu and J. Wu, Mol. Pharmacol., 2005, 68, 1831-1838.

38 K. Sakurai, T. Takeshita, M. Hiraizumi and R. Yamada, Org. Lett., 2014, 16, 6318-6321.

39 R. Yamada, T. Takeshita, M. Hiraizumi, D. Shinohe, Y. Ohta and K. Sakurai, Bioorg. Med. Chem. Lett., 2014, 24, 1839-1842.

40 R. Yamada, M. Hiraizumi, S. Narita and K. Sakurai, Asian J. Org. Chem., 2016, 5, 330-334.

41 M. Hiraizumi, R. Komatsu, T. Shibata, Y. Ohta and K. Sakurai, Org. Biomol. Chem., 2017, 15, 35683570 .

42 K. Sakurai, M. Hiraizumi, N. Isogai, R. Komatsu, T. Shibata and Y. Ohta, Chem. Commun., 2017, 53, 517-520.

43 M. Kuroda, Y. Mimaki, A. Yokosuka, Y. Sashida and J. A. Beutler, J. Nat. Prod., 2001, 64, 88-91.

44 M. Kuroda, Y. Mimaki, A. Yokosuka, F. Hasegawa and Y. Sashida, J. Nat. Prod., 2002, 65, 1417-1423.

45 T. Tschamber, S. Adam, Y. Matsuya, S. Masuda, N. Ohsawa, S. Maruyama, K. Kamoshita, H. Nemoto and J. Eustache, Bioorg. Med. Chem. Lett., 2007, 17, 5101-5106.

46 M. Nassal, Liebigs Ann. Chem., 1983, 1510-1523.
47 Z. Jin, Y. Mei, L. Chen and A. Shah, US Patent, WO2017/ 100153A1, 2017.

48 H. Chen, T. Xian, W. Zhang, W. Si, X. Luo, B. Zhang, M. Zhang, Z. Wang and J. Zhang, Carbohydr. Res., 2016, 431, 42-46.

49 T. Taniguchi and K. Monde, Chem. - Asian J., 2007, 2, 1258-1266.

50 R. U. Lemieux and R. M. Ratcliffe, Can. J. Chem., 1979, 57, 1244-1251.

51 H. Hashimoto, K. Araki, Y. Saito, M. Kawa and J. Yoshimura, Bull. Chem. Soc. Jpn., 1986, 59, 3131-3136.

52 P. H. Seeberger, S. Roehrig, P. Schell, Y. Wang and W. J. Christ, Carbohydr. Res., 2000, 328, 61-69.

53 T. Ohtani, S. Sakai, A. Takada, D. Takahashi and K. Toshima, Org. Lett., 2011, 13, 6126-6129.

54 L. S. Khasanova, F. A. Gimalova, S. A. Torosyan, A. A. Fatykhov and M. S. Miftakhov, Russ. J. Org. Chem., 2011, 47, 1125-1129.

55 Z. Pakulski and P. Cmoch, Tetrahedron, 2015, 71, 4757-4769.

56 Y. Yang and B. Yu, Tetrahedron, 2014, 70, 1023-1046.

57 X. Ma, B. Yu, Y. Hui, D. Xiao and J. Ding, Carbohydr. Res., 2000, 329, 495-505.

58 K. Kuczynska, P. Cmoch, L. Rárová, J. Oklešt'ková, A. Korda, Z. Pakulski and M. Strnad, Carbohydr. Res., 2016, 423, 49-69. 